\title{
7 THE VARANGIAN GUARD AND ITS CONTRIBUTION TO THE MANIFESTATION OF THE IMPERIAL POWER IN BYZANTIUM
}

\author{
Alexandra Airinei \\ "Alexandru-Ioan Cuza" University in Iași, E-mail: alexandraairinei@gmail.com
}

\section{Acknowledgements}

This paper was presented at the Sixth international conference on Baltic and Nordic Studies in Romania Historical memory, the politics of memory and cultural identity: Romania, Scandinavia and the Baltic Sea Region in comparison, organized by the Romanian Association for Baltic and Nordic Studies, Faculty of History and Political Sciences of Ovidius University of Constanța and International Summer School of The University of Oslo, Norway, May 22-23, 2015. Supported by a grant from Iceland, Liechtenstein and Norway, The EEA Fund for Bilateral Relations, contract no. 910/20.03.2015.

\begin{abstract}
:
The idea that motivated the writing of this article was to treat an aspect not only of the Byzantine military history, but also of the long lasting impression that this millenary empire has left on the Northern "barbarians", as they are often called in the Orthodox medieval sources. Its central concept is, as the title already suggests it, the imperial ideology of power, but from another perspective: the contribution of the feared Scandinavian warriors to its outlining in the Byzantine public life, as opposed to the emperor's private existence, always hidden from the eyes of his subjects. Also, I have tried to summarise a fragment of the Norse perception on Byzantium and in what manner it influenced the former participants at the Byzantine military campaigns when they returned home.

The paper has two main directions: first of all, the one that analyses the role of the Varangian guard in the life of the Basileus and their function in the display of his divine power. Secondly, the way in which the Scandinavian mercenaries perceived their military service and their proximity to the one considered imago Dei. Furthermore, this approach is preceded by a short history of the Varangian guard and its unique type of organisation inside the Byzantine army, as well as a short description of the Norse-Byzantine relations before the founding of this special unit.
\end{abstract}




\section{Rezumat:}

Ideea care a motivat scrierea acestui articol a fost aceea de a trata un aspect ce tine nu numai de istoria militară bizantină, dar și de impactul de lungă durată pe care acest imperiu milenar l-a avut asupra "barbarilor" nordici, așa cum erau aceștia adesea numiți în sursele medievale ortodoxe. Conceptul central este, aşa cum titlul deja sugerează, ideologia imperială a puterii, dar dintr-o altă perspectivă: contribuția temuților războinici scandinavi la conturarea ei în viața publică bizantină, spre deosebire de existența privată a împăratului, întotdeauna ascunsă ochilor supuşilor săi. De asemenea, am încercat să redau un capitol al percepției nordice asupra Bizanțului, și în ce mod aceasta i-a influențat pe foștii participanți la campaniile militare bizantine când aceștia s-au întors acasă.

Lucrarea are două direcții principale: în primul rând, cea care analizează rolul gărzii varege $\hat{\imath}$ viața basileilor si funcția lor $\hat{n}$ etalarea puterii divine a acestora. In al doilea rând, modul în care mercenarii scandinavi au perceput serviciul militar prestat și apropierea lor de cel considerat imago Dei. In plus, această abordare este precedată de un scurt istoric al gărzii varege și al tipului său unic de organizare în interiorul armatei bizantine, precum și de o scurtă descriere a relațiilor scandinavobizantine înainte de înființarea acestei unități speciale.

Keywords: Byzantine emperor, ideology of power, Varangian guard, military service

Who were the Varangians and what was the Varangian guard? Katherine Holman gives us a clear definition of its role and importance: "Scandinavians who travelled to Byzantium to serve in the emperor's bodyguard were generally known as Varangians. Scandinavians have entered imperial service from as early as the mid-ninth century, under Michael III [842-867], but a separate unit was not established until 988, when Basil II recruited Scandinavian mercenaries from Vladimir ${ }^{1}$ of Kiev. The Varangian guard became an elite unit of Scandinavian mercenaries and was the highest paid among the imperial guard." 2 . Consequently, the great sum of money that went to this army corps was directly proportional to its importance, because it did not have only a single mission - protecting the emperor. The same author states that, in The Primary Chronicle (more popularly known as Nestor's Chronicle) - one of the main sources for the

1 The Slavic version of the Norse name Valdemar.

2 Katherine Holman, Historical Dictionary of the Vikings (Lanham, Maryland and Oxford: The Scarecrow Press, Inc., 2003) 275. 
early history of Russia - the term "Varangian" is used for describing the Scandinavians in general ${ }^{3}$. Still, its overtones are deeper than that, the most obvious proof of this statement being the multitude of theories related to this word. I will not present here all of them, but only the one that seemed most plausible to me: Adolf Stender-Petersen's theory, according to which the term refers to the voluntary oath and to the unity of individuals who navigated together, having the aspect of a commercial fraternity. Ethimologically speaking, the Old Norse word væringjar derives from the word vár (várar being the plural), which in Nørront meant "trust in", "faith in" or "oath of fidelity". Given these facts, the word refers to the main activity of the Swedish vikings - commerce ${ }^{4}$. The people engaged in sea journeys in the East to sell their goods had to carry weapons and to make their own code of honour, in which solidarity was of the utmost importance. Gradually, væringjar began to refer only to Scandinavian mercenaries. 5

The Vikings entered in the service of the Emperor at the peak of their European invasion or the Viking Era - how the Anglo-Saxon historians call it. Its causes were fallaciously interpreted over time, often being considered from a unilateral perspective. Of course, they are numerous and I feel the need to restate some points that have dominated the historiography related to the Norse invasion in the last half a century. One factor that must be taken into consideration is overpopulation. As we know, in the past (as today), the geographical position of Scandinavia determines some areas to be almost impossible to inhabit, which leads to the overpopulation of others. This was the case of the Western area of the later Norwegian kingdom6, from where the expeditions to Orkney,

${ }^{3}$ Ibid., 276.

${ }^{4}$ Unlike their Norwegian and especially Danish neighbours, the Swedish did not have a propensity for pillaging, as they had for commercial voyages, reaching as far as the Islamic world and, it it is said, exchanging goods even with the Chinese Empire.

${ }^{5}$ Sigfús Blöndal, The Varangians of Byzantium, An aspect of Byzantine military history translated, revised and rewritten by Benedikt S. Benedikz, (New York: Cambridge University Press, 2007) 5-6.

" I did not say "Norwegian kingdom" because, at that time, the political entity was not yet formed. The Norwegian territory was made of petty kingdoms lead by several kings and jarls. The centralisation of these political entities will not take place until the last years of the $10^{\text {th }}$ and from the $11^{\text {th }}$ century on, along with the first Christian kings, Oláfr Tryggvason and Óláfr Haraldsson. 
Shetland or the Hebrides started. The Norwegians also settled in these regions. Another cause that led to the violent relation with the Europeans was the eagerness of the Vikings to find a quick way to gain wealth. This is the reason why the first targets were the monasteries. Not paganism and the specific intention to destroy the Christian sanctuaries determined the first invaders to devastate them, but the fact that these edifices were in the possession of numerous riches that could be taken without encountering too many difficulties. Once pillaged, the monasteries were lit on fire and the plunder was taken back home. This aspect leads to the next one - the reputation which the Vikings acquired at their return in their place of origin. Thereby, through wealth and fame (for being a warrior) many asserted themselves as kings. This is also the case of Christian kings - the best example is Haraldr harðráði Sigurðarson (Hard-Ruler) 7 . Furthermore, when speaking about the causes of the Scandinavian invasion we must not ignore the punishment practice for several crimes: exile (in this situation was Eiríkr rauði - The Red, whom the literary tradition remembers as the founder of the Viking settlement in Greenland). This way, the outlaws were determined to seek other places to abide; still, their numbers were not so great as it may seem. Nevertheless, their contribution was significant from another point of view: they attracted many other settlers or warriors, which had its part in this process already started by the violent attacks. Now we must not think that these aspects manifested themselves separately from each other. They had a simultaneous evolution, being part of the much wider historical phenomenon called The Viking Era. New boroughs appeared and developped: Dorestad (near Rhine, in the Netherlands), Quentovic (near Boulogne), Hamwic, Fordwich, London, Ipswich and York (in Britain). Here, the Vikings from Ribe (Denmark), Birka (Sweden), Truso (in the Baltic region) and Hedeby (former Danish possession, now German) traded their goods, especially skins. The trade with the Western world also represented a way for the chieftains to gain wealth, who later became kings $^{8}$. All of these causes are suitable for the Swedish Vikings as well, who

7 His brother, Óláfr Haraldsson, the king who christianised most part of the Norwegian territories and the saint patron of Norway, was also a pirate, as well as his predecessor, Óláfr Tryggvason.

8 Peter Sawyer, Viking Expansion, in Knut Helle, ed., The Cambridge History of Scandinavia, Vol. I. Prehistory to 1520, (Cambridge Histories Online, Cambridge University Press, 2008) , www.bookmoving.com /book/cambridge-historyscandinavia_98682.html, accessed 07.03.2014, 106-108. 
focused primarily on the East, but who (as already mentioned) were mostly traders.

The latter settled in the territories inhabited by Slavic populations, territories which later formed the Russian region. It was also them the ones who influenced the toponymy of the area, because their origin places Uppland and Östergötland - were known under the common name of Roper, Ropin or Roslagen, while the inhabitants were called Róðskarlar, Róðsmen or Róðspiggar. The North-Central Russia was called in Norrønt Svípjóð en mikla (The Great Sweden) or Svípjód en kalda (The Cold Sweden)9. Therefore, the Swedish can be found in different medieval sources, regardless of their author's origin, under the name of rus, rhos. Conventionally, the Scandinavian states formed in the Slavic regions were founded beginning with 862, from the foundation of Holmgard (near Novgorod) by Rurik ${ }^{10}$, but the archaeological findings indicate the fact that they had existed even earlier than this moment ${ }^{11}$. For the $9^{\text {th }}$ century, the Arab chronicler Ibn Khurradadhbeh mentions the Norse traders who came with skins and swords ( $r h o s, r \bar{u} s$ ) on the coast of the Black Sea and paid the Byzantines customs duties, most probably at Cherson. Furthermore, the same author confirms their existence at the court of the emperor even before 838 when it seems that they were send as a token of friendship by their chagan. To support the Arab chronicler, which firmly states peaceful relations between the Byzantines and the Vikings, the archaeologists have found in Scandinavia - Birka (Sweden), Hedeby, Ribe and Tissø (Denmark) - a number of Byzantine and Arab coins (one of them with the effigy of Teophilus, 829-842) and also an official Byzantine seal from the first half of the $9^{\text {th }}$ century ${ }^{12}$.

This is one aspect of the relations between the Byzantines and the Scandinavians settled in the Slavic space. The other side of the shield is represented by the consecutive attacks of the former on Constantinople that they were hoping to conquer. There are two great actions of this kind, mentioned also by the Byzantine chroniclers: the attack in June 860 , led by

\footnotetext{
${ }^{9}$ Blöndal, 1.

10 The Slavic version of the Old Norse name Rørik.

11 Ibid., 3.

12 Jonathan Shepard, The Viking Rus and Byzantium, in Stefan Brink and Neil Price, ed., The Viking World, (Taylor\&Francis eLibrary, 2008) www.divaportal.org/smash/get/diva2:132794/FULLTEXT01.pdf, accessed 02.11.2014, 497.
} 
two Swedish chieftains, Höskulðr and Dyr and the one led by prince Igor ${ }^{13}$ in 941. The first one is recorded by the Patriarch Photios, who sees in the destructions caused by the pagans a divine punishment (just like the rest of the Europeans), while the second one is reported by Liutprand of Cremona, who went personally to the court of Constantine VII Porphyrogennetos (913-959). The two expeditions are similar: the sources mention the cruelty of the Russians ${ }^{14}$, the burning of churches and killings of priests, but the similarities cannot be found only in the ferocity of the raids. Likewise, the two expeditions have failed, which was ascribed to the God of the Christians. They were followed by a number of baptisms (even though not as great as the sources claim) and, economically, by two commercial treaties between the two parts, extremely convenient for the Vikings.

John H. Lind offers an interesting perspective on these treaties, not necessarily on their stipulations, but more on what they reveal. He argues, based on the Russian medieval chronicle Povest' vremennych let (Nestor's Chronicle) which contains the texts of the three treaties $(907,911,944)$ that the Russian (the Varangians) were christianised before the people of the North. As an argument he clearly quotes the texts of the three diplomatic agreements, emphasizing on the oaths of the witnesses. Therefore, if in the first two treaties all of the Varangians made the vow in the name of their ancient religion and customs, the 944 text makes a clear distinction between the pagans and the baptised $R u s^{15}$. In my opinion, Lind's theory implies very clearly that the Scandinavians settled in the East adopted Christianity long before their "brethren" in the North. This also indicates that most of them entered the Varangian guard already baptised, and there they became even more closely acquainted with the new religion. Furthermore, if we take into consideration the fact that many of them returned to their homeland, we have to admit that they also carried the Christian doctrine with them. Still, there are three important questions that arise: Why would they become Christians all of a sudden, in such a short time (from 911 to 944 there are only 33 years, in which a new religion cannot defeat the

\footnotetext{
13 The Slavic Version of the Old Norse name Ingi or Ingvarr.

14 Actually, Rhos, the Scandinavians inhabiting the Slavic space.

15 John H. Lind, "Varangians in Europe's Eastern and Northern Periphery: The Christianization of the North and Eastern Europe c. 950-1050 - A Plea for a Comparative Study", in Ennen ja nyt, 4/2004, http://www.ennenjanyt.net/404/lind.pdf, accessed July 19th, 2015, 6-7.
} 
ancient, deeply rooted beliefs - there is not even a generation between the two treaties) ? and Did the Byzantine Empire have an active role in it? (It must have had, since it was the greatest power in the region and the biggest religious centre)? If so, why there are no other written proofs than the 944 treaty? Any religious victory must be registered, not only as an earthly victory, but as another step in expanding the Christian empire (understood in both ways: practically and metaphorically). Lind answers partially this question, by telling that they adopted Christianity "presumably by individual choice, perhaps while living in or visiting Byzantium"16. However, there is another question that remains not answered: Why would they do that if they had commercial benefits and a good political relation with the Empire without being Christian (as stipulated by the treaties themselves)?

The Byzantines knew very well the difference between the Rhos and the Slavic people, as it is shown by the Emperor Constantine VII Porphyrogennetos, in his famous work, De administrando imperio. When thoroughly describing the territories in which the former have settled, he provides the reader with various place-names, that he explains both in Old Norse, and in the mother-tongue of the local population: "[...] come down to the second barrage, called in Russian Oulvorsi and in Slavonic Ostrovouniprach [...]. Similarly they pass the third barrage also, called Gelandri, which means in Slavonic <Noise of the Barrage>, and then the fourth barrage, the big one, called in Russian Aeifor, and in Slavonic Neasit [...]."17 The origin of these Russians is also stated in The Annals of Saint Bertin: in 839, the Byzantine Emperor Teophilus sent at the court of Louis the Pious at Ingelheim an embassy, in order to confirm and consolidate the peace between them. "He also sent with the envoys some men who said they - meaning their whole people - were called Russians [Rhos in the

16 Idem, "Darkness in the East? Scandinavian Scholars on the Question of Eastern Influence in Scandinavia during the Viking Age and Early Middle Ages", in Line Bjerg, John Lind and Søren Sindbæk (Eds.), From Goths to Varangians: Communication and Cultural Exchange Between the Baltic and the Black Sea, (Aarhus: Aarhus University Press, 2012), 353.

17 Constantine Porphyrogennitus, De administrando imperio, Edited by Gy. Moravcsik, Translated by R. J. H. Jenkins, (Washington, D. C.: 1967, 49-51, 57-63). Scanned and proofread by Eric C. Knibbs, 2006, https://classesv2.yale.edu/access/content/user/haw6/Vikings/de\%20administr ando\%20imperio.html, accessed 19.04.2015. 
original text] and had been sent to him by their king whose name was the Khagan for the sake of friendship, so they claimed [...]." Teophilus asked Louis that he "might grant them safe conducts to travel through his empire and any help or practical assistance they needed to return home [...]. When the Emperor investigated more closely the reason for their coming here, he discovered that they belonged to the people of the Swedes."18 Historian Wladyslaw Duczko sees in this the preliminary aspects of a longer military collaboration between the Norse and the Byzantine Empire, as the latter needed military aid against the Muslim forces ${ }^{19}$. This theory does not stand when we examine closer the historical context: at that time, the Russian states have not yet been fully founded, even if archaeological traces record their scarce presence in the region. Furthermore, the two civilisations have not yet been truly connected in order for the Emperor to find in the newcomers the perfect soldiers for his personal guard (as Duczko states).

The turbulent relations with the latter showed the Byzantines the skills that the Swedish had in combat and the fact that, even departed from their origins places, had kept alive the values in which they were raised; among them, of paramount importance was loyalty and courage. Thus, in 988 - the year of Vladimir/Valdemar, prince of Kiev's baptism -, the emperor Basil II (867-886) asked him for a contingent of Russian warriors to help him defeat the rebellion of Bardas Phocas ${ }^{20}$. About this moment, Michael Psellus states: "[...] a picked band of Scythians ${ }^{21}$ has come to help him from the Taurus. These men, fine fighters, he had trained in a separate corps, combined with them another mercenary force, divided by companies, and sent them out to fight the rebels." 22 That was the beginning of a new army corps, the Varangian guard, elite unit favoured by the

18 The Annals of Saint Bertin, Translated by Janet Nelson, (Manchester: 1991) Scanned and proofread by Knibbs,2006,https:/ / classesv2.yale.edu/access/content/user/haw6/Vikings/Ann als\%20of\%20st\%20Bertin\%20839.html, accessed 19.04.2015.

${ }_{19}$ Wladyslaw Dukzco, Viking Rus: Studies on the Presence of Scandinavians in Eastern Europe (Leiden, Boston: Brill, 2004), 44-45.

20 Hilda Roderick Ellis, The Viking Road to Byzantium, 177-192, www.archeurope.com/_texts/0005.pdf, accessed November 22, 179.

${ }^{21}$ Russians, Rhos.

${ }^{22}$ Fourteen Byzantine Rulers - The Chronographia of Michael Psellus, Translated, with an introduction by E. R. A. Sewter, (Harmondsworth, Middlesex: Penguin Books, 1966), 35. 
universal monarch. As Raffaele d'Amatto states, Basil II "needed a guard who would be uncompromisingly loyal to their paymaster; he needed a regiment of exceptional fighters, well disciplined and trained, whose foreign mercenary status insulated them from the regional and court intrigues and political and religious factionalism of the Byzantine aristocracy and population." 23 John Skylitzes gives us a clue about the enrolment of the Rhos in the Imperial Guard: a certain Chrysoceir ${ }^{24}$ "took with him eight hundred companions and, on several ships, he came to Constantinople under the pretext that he wants to enrol as a mercenary." 25 John $\mathrm{H}$ Lind states in a very convincing manner who were the Norse enrolled in the Emperor's personal guard: they must have come from the higher nobility, first of all because they were the ones who had access to a solid military training and, secondly, because they were the ones who could bear the enormous costs implied by the voyage to Byzantium and the entrance fee ${ }^{26}$.

The imperial guard had two main components: the Great and the Small Hetairia, but there was one time when there was also a Middle Hetairia. These were the units the Swedish enrolled in increasingly great numbers, being attracted by the wealth they could have earned in not such a long time. Each new member had to bring his own pecuniary contribution, according to the subunit they wanted to be part of. Most probably they received by the emperor himself with a part of the money. Furthermore, they had much bigger remunerations compared to the rest of the troops, they received gifts at Easter, with the occasion of a new emperor's coronation and their share of the plunder. The captain of the Hetairia was the Great Hetairiarch, whose main responsibility was the safety of the monarch, guarding him especially against treason and he was, as a general rule, a member of the Byzantine aristocracy. ${ }^{27}$ Their main weapons were the axe, the arrows and the spear (most of the times, they were similar to the Norse typologies) and, for defending themselves, they

\footnotetext{
${ }^{23}$ Raffaele d'Amatto, The Varangian Guard 988-1453 (Oxford: Osprey Publishing, 2010), 7.

24 This is definitely not a Scandinavian name; the author does not offer any details on his origin. It may be, as well, a transformation of this character's original name. ${ }^{25}$ Jean Skylitzes, Empereurs de Constantinople, texte traduit par Bernard Flusin et annoté par Jean-Claude Cheynet, (Paris : Éditions P. Lethielleux, 2003) 305.

${ }^{26}$ John H Lind, “Darkness [...]”, 354.

27 Ellis, 178-182.
} 
had coats of mails, helmets, knee caps and round shields. ${ }^{28}$ They even had their own banner, called drakonarioi: a bronze sculpture of a dragon head, in which were fit in silk ribbons. This type of banner is also depicted on the Bayeux Tapestry, being carried by some nobles around Harald Godwinson. The main duty of the Varangians was watching over the emperor, but their responsibilities went far beyond that. They were guarding the Chalke Gate $^{29}$ of the Great Palace, the hall where the emperor signed the official documents and the main rooms in Blachernae. During receptions, the Vikings were standing around the imperial throne. Moreover, they also had police duties and were guarding the prisons. From what Anna Comnena wrote in the chronicle dedicated to her father, Alexios I, - The Alexiad - , they were also used for torturing the prisoners. According to her, the Byzantine aristocrats Michael Anemos, George Basiliacos and John Solomon plotted against Alexios, but they failed. The latter was captured and interrogated by the emperor: "Solomon looked fixedly at him, and then at the barbarians standing in a circle around the Sebastocrator ${ }^{30}$, brandishing their one-edged axes on their shoulders, and forthwith fell to trembling, and revealed everything and gave the names of his fellow plotters [...]." 31

The discipline was very strict inside the unit and it seems striking at first the fact that the Varangians who committed crimes were judged separately, after their own laws, by their own comrades. A good example to illustrate it is told by Grettis Saga, where the main character - Grettir -, a feared Icelandic outlaw, is killed for his deeds by Porbjörn. The latter will be exiled for using magic to punish the former and because he murdered a sick, weak man - Grettir was dying when he was killed. Porbjörn left Iceland for Constantinople - Miklagård ${ }^{32}$-, but he was followed by Porstein, Grettir's brother, who wanted to avenge his death. Both of them enrolled in the Varangian guard, during Michael IV's reign (1034-1041). Porstein discovered Grettir's killer when the unit was at a "weapon show" - a custom which seems to have been respected since the foundation of the

\footnotetext{
28 Blöndal, 183-184.

${ }^{29}$ Literally, "The Bronze Gate".

${ }^{30}$ Literally, it means "The venerable ruler" and it was a honorific court title created by Alexios I himself, being the highest below the emperor.

31 Anna Comnena, The Alexiad, Translated by Elisabeth A.S. Dawes, (Cambridge, Ontario: In Parentheses Publications, Byzantine Series, 2000) 222.

32 Old Norse name for Constantinople, meaning "The Great City".
} 
army corps: "The custom and the law were that before they marched a review was held for the inspection of their weapons; this was done on the present occasion." 33 Porbjörn showed proudly the sword which he killed Grettir with and he was also killed by his brother. It is certain that the other members of the guard did not punish Porstein for this and he was even defended by the others when the Byzantine authorities arrested him. Even though sögur cannot be regarded as authentic historical sources, they are useful in outlining the main characteristics of the period. This is what Grettis Saga actually does: it indicates once more (besides the Byzantine chronics) the fact that, even though the Varangians were in the scope of the Byzantine law, they were primarily judged by their comrades, as I previously said, according to the Scandinavian laws. From this saga we can draw another conclusion: the self-consciousness that the Varangians had "Both wanted to be received into the Varangian Guards, and their offer was well received directly it was known that they were Norsemen." 34 A contribution to this self-consciousness was brought by the emperor himself, who not only avoided their assimilation by the local population, but he also encouraged the particularities of his guards, building them their own church $^{35}$. This was most probably the very purpose of the monarchs: the fact that the Scandinavians represented "the other" not only politically, but also religiously, made them disagreeable to the Byzantines and, therefore, it kept them away from the plots. Furthermore, these cultural hallmarks were the ones that made them so loyal. They are reflected even on the crest illustrated on their shields: the raven ${ }^{36}$, odinic bird par excellence, but also an "instrument" used to find the direction in which they could get to the shore when travelling by ship. However, one of the most important aspects is, in my opinion, the fact that they were allowed to keep their mother tongue Norrønt. Again, this can be best illustrated by the episode of the arrival of the Dane king Eiríkr ejegoð (The Good) in Constantinople in 1103 . He talked to the Varangians who were in service of the emperor in their own

33 Grettir's Saga, Translated by William Morris and Eirikr Magnusson, 1900, sagadb.org/grettis_saga.en, accessed 23.11.2014, C86.

34 Ibidem, C86.

35 This matter is still debated by historians; it is still uncertain whether the church was dedicated to Virgin Mary or to Saint Óláfr.

${ }^{36} \mathrm{D}^{\prime}$ Amatto, 35. 
language ${ }^{37}$. Also, it is known the fact that the Byzantines could understand them only with the help of a translator. Another medieval source that records precisely these peculiarities of the Varangians within the Emperor's army is, this time, a Byzantine one. John Skylitzes relates an episode from Michael IV Paphlagonian's reign (1034-1041), which happened on the territory of the Thracian theme (in South-Eastern Balkans): one of the Varangians tried to dishonour a local woman, who managed to defend herself and eventually kill him. "[...] The Varangians, assembled, surrounded the woman, to whom they gave all the wealth of his violator; as about him, they threw his body without a grave, like they do to criminals." 38

The fact that they were feared warriors, "ruthless, frenzied fighters" 39 as Travis Shores describes them, the Varangians made it easier for the Eastern emperor to manifest its power. Their imposing presence on the battlefield indicated that of the sovereign. They were guarding his tent, having their own situated around it. Furthermore, when they were on a military campaign in a provincial town, the keys of this town were offered to them by the authorities. Likewise, the Scandinavians were exclusively tied to the emperor's person. Only in exceptional cases they could be appointed to stand by another member of his family and only if that person was part of the high nobility. This appeared every time as a favour made by the basileus and, what is more, it was meant to emphasize the fact that the people in question were privileged (a classic example is that of John Palaeologus, Michael VIII's brother).

The Varangians were a constant presence in the life of the Byzantine ruler even when he was signing the official documents in the room called kellion, as well as in the Triklinion - the main reception hall in the Blachernae. They were there when a foreign delegation was received and a high rank member was carrying the shield and the banner of the Eastern monarch. 40 Haraldr harðráði Sigurðsson himself, the king of the

${ }^{37}$ F. Donald Logan, The Vikings in History, Second Edition, (Taylor \& FranciseLibrary: 2003) ollietulett.com/the-vikings-in-f-donald-logan.html, accessed 9.11.2014, 196.

${ }^{38}$ Skylitzes, 327.

${ }^{39}$ Travis Shores, Varangians: Norse Influences within the Elite Guard of Byzantium, https://www.academia.edu/3628861/Varangian_Norse_Influences_Within_the_E lite_Guard_of_Byzantium, accessed 23.11.2014, 16.

${ }^{40}$ Blöndal, 178-179. 
Norwegian territories between 1046 and 1066 and one of the three rulers who fought for the conquest of England in 1066 (he died in the battle of Stamford Bridge, September $25^{\text {th }}$ ), was a member of the Varangian guard. He filled the rank of Manglabites, being responsible with walking in front of the emperor with the occasion of certain processions and carrying a whip studded with gems in order to control the crowds. ${ }^{41}$

As far as the religious ceremonies are concerned, the Varangians always escorted the emperor on a definite track and up to a given point. For example, on Candlemass, the basileus went from the palace up to the church Saint Mary of Blachernae; his guards went up to the church as well, but after that they returned to the Hypsela Gate, where they waited having the axes on their shoulders. On The Nativity of Saint John the Baptist, the Varangians had to go as far as Petra Monastery, and on the Advent - up to Studion Monastery. With the occasion of the coronation of a new emperor, the Norsemen marched on both sides of the new crowned sovereign and, after raising him on the shield, they were also the ones who brought him to be displayed in front of the subjects who acclaimed him. After the ceremony, they were given gold and silver coins from the lap of the emperor. At feasts, they presented their compliments to the basileus along with the high aristocracy and the foreign diplomats and the most interesting fact is that they did it in their native language. On Christmas, they had to march in front of the Imperial banner and in front of another twelve that bore the icons of saints (most of them being military saints). In my opinion, the engagement of the Varangian guard in every aspect of the Byzantine public life had an enormous influence on those who served in the Imperial army, as they were thus closely acquainted with Christianity and they could notice its advantages from the perspective of power, its legitimation and manifestation. This idea is also confirmed by their presence in the church, where the emperor was sitting on a high seat during service, while the Varangians were standing behind him, holding their axes until he actually took his seat and, after that, they placed them on their shoulders ${ }^{42}$.

We can see that, during each ceremony, the Vikings who surrounded the Byzantine ruler always had with them (and it was actually part of their parade) the weapon that made them so famous: the axe. Anna

\footnotetext{
${ }^{41}$ Ellis, 183.

42 Blöndal, 179-181.
} 
Comnena talks about them as "axe-bearing barbarians". However, what she managed to illustrate more than the other medieval chroniclers is precisely the reason why these "barbarians" became so important in the emperor's life and ceremonial manifestations of power: "The Varangians, too, who carried their axes on their shoulders, regarded their loyalty to the Emperors and their protection of the imperial persons as a pledge and ancestral tradition, handed down from father to son, which they keep inviolate and will certainly not listen to even the slightest word about treachery." 43

Another Byzantine author who gives us more insight on the Varangian guard is Niketas Choniates. Even if he wrote in the second half of the $12^{\text {th }}$ century, when the mercenary unit was made up mostly from English soldiers who left their homeland after 1066, the information can definitely be applied to the Scandinavian fighters as well. Of course, their most prominent characteristic was the weaponry. Hence, Choniates calls them "axe-bearing barbarians" as well44. However, unlike Anna Comnena, he gives details about the specific of their weapons: "single-edged axes" and "long shields", which they used to defend the emperor John Comnenos "like an unbreakable wall" 45 .

All this trust that the basileus reposed in the Varangian guard and every facility that they got (for example, there was an obligation from the householders - even from the monasteries - regarding the housing of the imperial troops ${ }^{46}$ ), without taking into consideration the enormous sums of money they earned, made the Scandinavians arrived in gradually greater numbers in Constantinople to enter the emperor's service. This was also a useful military exercise, because they were sent to the main theatres of operations, riches that they could bring back to Scandinavia and, most important, the fame as skilled warriors. Even if it was christianised after 1000, the Northern Europe remained for some while faithful to the old pagan traditions and beliefs and, even though there was an attempt to introduce the right of primogeniture at the end of the $12^{\text {th }}$ century, it failed

\footnotetext{
43 Comnena, 46.

44 O, City of Byzantium, Annals of Niketas Choniates, Translated by Harry J. Magoulias (Detroit: Wayne State University Press, 1984) 189.

45 Ibid., 11.

46 Blöndal, 82.
} 
after a few years. Thus, the old criteria remained valid: battle skills and wealth.

The attraction towards Byzantium is stated in almost every Scandinavian early medieval writings, when one of the characters decides to go East. For example, in Laxdæla Saga, one of the main characters - Bolli Bollason - goes to Miklagård willing to discover and to be acquainted with more than his native Icelandic territories. He entered the Varangian guard and, after a few years, he returned to his origin place full of riches: "He had on the clothes of fur which the Garth-king47 had given him, he had over all a scarlet cape; and he had Footbiter ${ }^{48}$ girt on him, the hilt of which was dight with gold, and the grip woven with gold; he had a gilded helmet on his head and a red shield on his flank, with a knight painted on it in gold. He had a dagger in his hand, as is the custom in foreign lands [...]." 49 As I have already mentioned, sögur cannot be trusted as authentic historical sources, but they recreate facts and ideas that cannot be ignored in the researches regarding the Scandinavian area. We can imaginate the impact that must have had on the others the return of a warrior from Byzantium.

The most famous case is that of Haraldr harðráði Sigurðsson. The step brother of Óláfr Haraldsson, the one considered saint patron of Norway, who christianised the biggest part of the territories, he was forced to run away after the latter had died in the battle of Stiklestaðir (1030). After living a while at the Court of Prince Jaroslav of Kiev, he left for Constantinople, where he served in the Varangian guard. Snorri Sturluson, the renowned Icelandic chronicler, dedicated him an entire saga in which he minutely recited the adventures of the royal offspring in Miklagård, during the reign of empress Zoe and Michael V Kalaphates (1041-1041) and, after that, of Constantine IX Monomachos (1042-1055). Serving in the basileus' personal army unit, he later asserted himself as the king of Norway and even fought for England's conquest. In Heimskringla too is clearly stated the fact that the Varangians submitted themselves to their own laws: " $<$ I deemed it would be a right of the Værings here within the realm of the King of Greeks, that they should be masters of their own matter, and be

\footnotetext{
${ }^{47}$ Garpr konungr in Old Norse - phrase used to refer to the Byzantine emperor. ${ }^{48}$ The name of Bolli's sword, Fótbítr in Old Norse.

${ }^{49}$ Laxdxla Saga, Translated from the Icelandic by Muriel A.C. Press, (London: J. M. Dent and Co., Aldine House, 1899) www.gutenberg.org/files/17803/17803h/17803-h.htm, accessed 23.11.2014, 268-269.
} 
free in all matters before all men, and be bound in service to the king only and the queen. $>$ "50 Haraldr fought in numerous battles, including the ones in Jerusalem where, according to Sturluson, he had the occasion to make a ritualic gesture of an enormous symbolic importance: he bathed in the waters of the Jordan river, like an authentic typus Christi, like an authentic Christian sovereign (which, of course, he was not, but the medieval chronicles are trying to portray the Scandinavian kings like genuine augustinian reges justi). He was thrown in jail after his return in Constantinople and, after he got out, he was part of the Varangian group that blinded Michael V Kalaphates (some sources say that it was Haraldr himself who did that), even though Snorri Sturluson does not want to admit his involvement ${ }^{51}$. This is the first of the two events in which the Scandinavians were involved in Court intrigues. The second is the conflict between Michael VI Bringas (1056-1057) and Isaac I Komnenos (1057-1059) in 1057, when they fought on both sides.

There are other Scandinavian sources that relate Haraldr's adventure in Byzantium. One of them is Ágrip af Nórgeskonungasogum, which relates Haraldr's return to Norway full of riches and with the fame of a "powerful man who had done many great deeds abroad [...]"52. Of course there are many other sources relating Harald's departure, but not many of them offer more that the simple mention of it. Another one could be considered Fagrskinna, which details the kings' adventures in Miklagård. Most of the episodes narrated are similar to the ones found in Heimskringla, but there is one crucial episode that differentiates the two: the moment when Haraldr blinds the Emperor himself. Even if Fagrskinna tells us that emperor Constantine Monomachos was the one blinded (and not Michael Kalaphates, the one who was actually punished for his deeds - in reality we do not know whether Harðaða was the one to do it), the source

50 Snorri Sturluson, The Stories of the Kings of Norway Called the Round World (Heimskringla), Vol. III, Done into English out of the Icelandic by William Morris and Eiríkr Magnusson (London: Chiswick Press, 1895) 60.

${ }^{51}$ Ibid., 74.

52 Ágrip af Nórgeskonungasogum/A Twelfth-Century Synoptic History of the Kings of Norway, Edited and translated with an introduction and notes by M. R. Driscoll, Second Edition (London: University College London, Viking Society for Northern Research, 2008), 53. 
indicates without any doubt that the future Norwegian king did it: he "[...] seized the king himself and put out both his eyes." 53

To better understand Haraldr's policy towards the Church, we must take a look at the relations between the Byzantine emperor and the ecclesiastical institution. The historians have erroneously interpreted it using the term of caesaropapism, or the basileus' position as the head of the Church and his supreme judgement in terms of religious matters. This is false, as the state and the Church were considered a single entity, according to the Roman and Christian political thinking. In this sense, it had to recreate the heavenly model of "the City of God" and thus the social peace and the religious order could not be dissociated. The emperor was responsible for maintaining both of them, which meant that he could interfere in ecclesiastical matters, but only up to a point, as he was not ordained, but rather considered "an outside bishop". In my opinion, this politico-theological conception was appealing to Haraldr Sigurðsson, who took it even further after he became a king. He manifested an unconcealed tendency of separating the young Norwegian Church from the Archbishopric of Hamburg-Bremen and appointed in his kingdom bishops ordained somewhere else (most of them in England), thus violating the rights of the latter. A conflict arose between the two parts, but it consumed quickly. It is said that, in his defence against the archbishop's pretentions, Haraldr stated that " $<$ he know of no other archbishop or master in Norway than the king himself. $>$ "54

After 1066, more and more Anglo-Saxons began to enter the Varangian guard. After 120455 , there are sources that certify the presence of a small part of it in Nicaea and the Despotate of Epirus and, under the Palaiologos (after 1261), they can be found in Constantinople. Even though they kept their functions, the members of the guard did not keep their prestige. Their time of glory had died.

\footnotetext{
53 Fagrskinna: A Catalogue of the Kings of Norway, A translation with introduction and notes by Alison Finlay (Leiden, Boston: Brill, 2004), 189.

54 Claus Krag, The Early Unification of Norway, in Knut Helle, ed., The Cambridge History of Scandinavia, Vol I Prehistory to 1520, (Cambridge Histories Online, Cambridge University Press: 2008) www.bookmoving.com /book/cambridgehistory-scandinavia_98682.html, accessed 07.03. 2014, 197.

55 The Fourth Crusade, which led to the almost complete destruction of Constantinople by the Western warriors.
} 
To conclude with, the Varangians were a constant presence in the history of the Byzantine Empire, being instrumental to the manifestation of the emperor's power in all its patterns. On one hand, having a different aspect and being known for their ferocity, they were unlikable to the Byzantines, but they assured a climate of security around the imperial persona, embodying an imposing sight at each and every ceremony and, furthermore, being given a central role. On the other hand, the Vikings themselves used the Byzantine experience to the fullest to gather wealth and fame and to assert themselves as genuine rulers in their origin places. 


\section{References:}

***. Grettir's Saga. Translated by William Morris and Eiríkr Magnusson, 1900. sagadb.org/grettis_saga.en, accessed 23.11.2014.

***. Laxdæla Saga. Translated from the Icelandic by Muriel A.C.

Press. London: J.M. Dent and Co., Aldine House, 1899. www.gutenberg.org/files/17803/17803-h/17803-h.htm, accessed 23.11.2014.

Blöndal, Sigfús. The Varangians of Byzantium, An aspect of Byzantine military history translated, revised and rewritten by Benedikt S. Benedikz. New York: Cambridge University Press, 2007.

Brink, Stefan, Price, Neil, ed. The Viking World. Taylor\&Francis eLibrary: 2008. www.divaportal.org/smash/get/diva2:132794/FULLTEXT01.pdf, accessed 2.11.2014. Comnena, Anna. The Alexiad, Translated by Elisabeth A.S. Dawes. Cambridge, Ontario: In Parentheses Publications, Byzantine Series, 2000.

Constantine Porphyrogennitus. De administrando imperio, Edited by Gy. Moravcsik, Translated by R. J. H. Jenkins. Washington, D. C.: 1967, pp. 49-51, 57-63. Scanned and proofread by Eric C. Knibbs,2006,https://classesv2.yale.edu/access/content/user/haw6/Vikin gs/de\%20administrando\%20imperio.html, accessed 19.04.2015.

D'Amatto, Raffaele. The Varangian Guard 988-1453. Oxford: Osprey Publishing, 2010.

Holman, Katherine. Historical Dictionary of the Vikings. Lanham, Maryland and Oxford: The Scarecrow Press, Inc., 2003.

Fourteen Byzantine Rulers - The Chronographia of Michael Psellus, Translated, with an introduction by E. R. A. Sewter, Harmondsworth, Middlesex: Penguin Books, 1966.

Krag, Claus. The Early Unification of Norway, in Helle, Knut, ed. The Cambridge History of Scandinavia. Vol. I Prehistory to 1520. Cambridge Histories Online, Cambridge University Press: 2008, www.bookmoving.com/book/cambridge-history-scandinavia_98682.html, accessed 07.03.2014.

Lind, John H, "Varangians in Europe's Eastern and Northern Periphery: The Christianization of the North and Eastern Europe c. 9501050 - A Plea for a Comparative Study", in Ennen ja nyt, 4/2004, http:/ / www.ennenjanyt.net/4-04/lind.pdf, accessed July 19th, 2015. 
Idem, "Darkness in the East? Scandinavian Scholars on the Question of Eastern Influence in Scandinavia during the Viking Age and Early Middle Ages", in Line Bjerg, John Lind and Søren Sindbæk (Eds.), From Goths to Varangians: Communication and Cultural Exchange Between the Baltic and the Black Sea, (Aarhus: Aarhus University Press, 2012).

Logan, Donald F. The Vikings in History. Second Edition, Taylor\&Francis e-Library: 2003, ollietulett.com/the-vikings-in-f-donaldlogan.html, accessed 9.11.2014.

O, City of Byzantium, Annals of Niketas Choniates. Translated by Harry J. Magoulias. Detroit: Wayne State University Press, 1984.

Roderick-Ellis, Hilda. The Viking Road to Byzantium, p. 177-192. www.archeurope.com /_texts/0005.pdf, accessed 22.11.2014.

Sawyer, Peter. Viking Expansion, in Helle, Knut. ed. The Cambridge History of Scandinavia. Vol. I Prehistory to 1520. Cambridge Histories Online, Cambridge University Press: 2008, www.bookmoving.com/book/cambridge-history-scandinavia_98682.html, accessed 07.03.2014.

Shores, Travis. Varangians: Norse Influences within the Elite Guard of Byzantium.

https://www.academia.edu/3628861/Varangian_Norse_Influences_Withi n_the_Elite_Guard_of_Byzantium, accessed 23.11.2014.

Skylitzes, Jean. Empereurs de Constantinople. Texte traduit par Bernard Flusin et annoté par Jean-Claude Cheynet. Paris: Éditions P. Lethielleux, 2003.

Sturluson, Snorri. The Stories of the Kings of Norway Called the Round World (Heimskringla). Vol. III, Done into English out of the Icelandic by William Morris and Eiríkr Magnusson. London: Chiswick Press, 1895.

The Annals of Saint Bertin. Translated by Janet Nelson. Manchester: 1991. Scanned and proofread by Erik C. Knibbs, 2006. https:// classesv2. yale.edu /access /content / user/haw6/Vikings/Annals\%20of\%20st\%20Bertin\%20839.html, accessed 19.04.2015. 